\title{
Fluoride distribution in underground water of district Mahendergarh, Haryana, India
}

\author{
Sucheta Yadav ${ }^{1} \cdot$ Sudhir Kumar Bansal ${ }^{2} \cdot$ Sanjay Yadav $^{3} \cdot$ Sunil Kumar $^{4}$
}

Received: 17 August 2018 / Accepted: 15 March 2019 / Published online: 28 March 2019

(c) The Author(s) 2019

\begin{abstract}
High fluoride concentration in groundwater occurs in majority of the dry and semidry regions of the Indian subcontinent. Mahendergarh district of Haryana state has been identified as Red Alert zone of high fluoride by Geological Survey of India (GSI). Most of the residents of Mahendergarh district are using ground water for drinking and irrigational purposes. The main purpose of the present study was to analyze the level of fluoride in ground water in all the eight blocks, i.e., Satnali, Sihma, Narnaul, Mahendergarh, Nizampur, Ateli, Kanina and Nangal Chaudhary of Mahendergarh district. Water samples were collected from 355 villages of the study area during December 2016 to May-June 2017 and were analyzed to find out the fluoride concentration with ion-selective electrode method. The fluoride distribution in Mahendergarh district ranged from 0.3 to $16.0 \mathrm{mg} / \mathrm{l}$ in ground water samples. Lowest value of $0.3 \mathrm{mg} / \mathrm{l}$ was reported in Dalanwas village of Satnali block and highest value of $16.0 \mathrm{mg} / \mathrm{l}$ in Narnaul city of Narnaul block. The outcome of the study revealed that out of 355 villages of the district, the fluoride level in 205 villages was found within the upper acceptable limit prescribed by WHO, i.e., $1.5 \mathrm{mg} / \mathrm{l}$. The fluoride concentration in 150 villages was above permissible limit that may cause fluorosis among residents of the district. The fluoride distribution pattern showed that the high fluoride level was observed in the central part and the lowest in northwest part of the study area.
\end{abstract}

Keywords Fluoride · Ground water · Fluorosis · Mahendergarh

\section{Introduction}

All over the world, poor drinking water quality is mainly accounted for $80 \%$ of the human diseases (WHO 1984). Worldwide, more than 200 million people are using fluoride contaminated water for drinking purpose (Ayoob and Gupta 2006). Fluoride is non-biodegradable element which is the most phototoxic among pollutants and accumulates in plants, soil and water from low to high concentration (Fornasiero 2001). In the earth lithosphere, fluoride is the 13th most

Sunil Kumar

sunilevs@yahoo.com

1 Department of Geography, Pt. N.R.S. Govt. College, Rohtak 124001, India

2 Department of Geography, M.D. University, Rohtak 124001, India

3 Kisan Aayog Haryana, Anaj Mandi, Sector-20, Panchkula 134116, India

4 Department of Environmental Sciences, M.D. University, Rohtak 124001, India abundant element (Gikunju et al. 1992). Fluoride concentration in the atmosphere is $0.5 \mathrm{mg} / \mathrm{m}^{3}$, but anthropogenic activities increase its concentration. In sea water, fluoride concentration is considered $1.3 \mathrm{mg} / \mathrm{l}$. Fluoride concentration in soil varies between 20 and $500 \mathrm{mg} / \mathrm{kg}$ (Edmunds and Smedley 2005). In biosphere, fluorine occurs in trace amounts in all kind of foodstuffs (Kundu et al. 2001). Fluoride is an essential oligo-element that prevents dental carries, and it is beneficial for formation of dental enamel and develops the bones (Park 2011; McDonagh et al. 2000; Bouletreau et al. 2006; Messaitfa 2008). There are numerous sources of fluoride, but the major source is due to the ingestion of drinking water (Kumari and Rao 1993). Drinking water is the most common way by which fluoride enters the food chain. In minute quantity, fluoride has beneficial effect on human health. If fluoride is ingested in more quantity above the permissible limit of $1.5 \mathrm{mg} / \mathrm{l}$ (WHO 2002, 2011), it causes dental and skeletal fluorosis (Sushila et al. 1993).

Sources of fluoride contamination in drinking water are both natural and anthropogenic activities. Marine aerosols, volcanic eruptions, some geothermal activities 
and fluoride bearing rock's minerals are mainly natural sources of fluoride in environment. Apart from these natural sources, there are some anthropogenic sources also that increase the fluoride concentration in environment. Industrial aerosols and phosphate fertilizers plants, sewage sledges and pesticides are main anthropogenic sources for high concentration of fluoride in soil and water (EPA 1997; Fuge and Andrews 1988; Cronin et al. 2000; Feng et al. 2003; Bonvicini et al. 2006; Walna et al. 2007). There are some other minor factors also that affect the fluoride level in groundwater such as temperature, $\mathrm{pH}$ of water and soil, soil's sorption capacity (Cronin et al. 2000), depth of well and climatic conditions of any area (Handa 1975).

Earth's crust has 85 millions tones of fluoride deposits, and out of this, 12 billion tones are found in India (Teotia and Teotia 1994). Geographical area is related to high concentration of fluoride that includes the East African Rift system (range from Jordan in northern Africa to Kenya and Tanzania in east Africa), large tracts of the middle east (Iraq, Iran, and Syria) and Indian subcontinent (Sri Lanka, Pakistan, India), Argentina, northern China and western USA. Dissanayake (1991) conducted a survey in Sri Lanka and found that fluoride level was above $4 \mathrm{mg} / \mathrm{l}$ in Sri Lanka. Alabdulaaly et al. (2013) conducted a survey in 13 regions of Saudi Arabia's Kingdom to examine the concentration of fluoride from 1060 water samples. The maximum range up to $5.40 \mathrm{mg} / \mathrm{l}$ was reported from Quassim province.

Geological Survey of India (GSI) has identified some areas as Red Alert zone of high fluoride in India: Nalgonda district in Andhra Pradesh; Gurgaon, Hisar, Fatehabad, Mahendergarh and Rewari district of Haryana; Fazilka and Jalalabad in the border district of Ferozpur in Punjab; Dindigul district in Tamil Nadu; Sindh district in Madhya Pradesh; Beed district in Maharashtra and parts of Unnao, Rae Bareilly and Sonbhadra in Uttar Pradesh. Ground water studies on fluoride level in India showed the high fluoride concentration in different parts of country (Gupta et al. 1993; Handa 1975; Indu et al. 2007; Reddy et al. 2010). The amount of fluoride contamination in India ranges from 1.0 to $48.0 \mathrm{mg} / \mathrm{l}$ (Sushila 2001). A survey was conducted to investigate the level of fluoride in groundwater of Vellore District, Tamil Nadu, South India, and observed that the fluoride concentration range in the area was between 0.02 and $3.0 \mathrm{mg} / \mathrm{l}$ (Kumar et al. 2014). Dahariya et al. (2015) collected 48 ground water samples from the tubewells of Donagarh city of Chattisgarh, India, in the pre-monsoon (May) and post-monsoon (January) period 2014. Fluoride concentration ranged from 2.1 to $10.3 \mathrm{mg} / \mathrm{l}$ in pre-monsoon and 2.7 to $12.7 \mathrm{mg} / \mathrm{l}$ in post-monsoon. Dhanya and Shaji (2017) noted that the fluoride content ranged from 0.68 to $2.88 \mathrm{mg} / \mathrm{l}$ in Alleppey, Kerala. In the present study, fluoride concentration has been examined in eight blocks of Mahendergarh district of Haryana state in India by ion-selective electrode method.

\section{Materials and methods}

\section{Study area}

The district Mahendergarh is located at extreme end of the southwest end of Haryana state located between $27^{\circ} 47^{\prime}$ to $28^{\circ} 26^{\prime}$ north latitudes and $75^{\circ} 56^{\prime}$ to $76^{\circ} 51^{\prime}$ east longitudes (Fig. 1). The total population of Mahendergarh district was $9,22,088$ as per 2011 census. Total geographical area of Mahendergarh district is $1899 \mathrm{~km}^{2}$. Administratively, the district has been divided into three sub divisions-Mahendergarh, Narnaul and Kanina. The district comprises of eight blocks-Ateli, Kanina, Mahendergarh, Narnaul, Nangal Chaudhary, Nizampur, Satnali and Sihma. It is inhabited by 370 villages and five towns, namely Ateli, Narnaul, Mahendergarh, Kanina and Nangal Chaudhary. The district headquarter is at Narnaul. Hot summer and cold winter are the main characteristic of the district. The climate is very hot tropical to subtropical characterized by high temperature and moisture deficiency for the greater part of the year. Annual rainfall of the district is $500 \mathrm{~mm}$ which is unevenly distributed over the area. The study area is lack of any perennial river system; however, some seasonal streams-Sahibi, Dohan and Krishnawati, are active only during the rainy days. Light-colored arid soils are found in the major part of the district. The hill ranges are marked features of the district which are part of great Aravali chain. Quartz, lime stone, marble, sandstone, iron or silica sand, feldspar and calcite are some important minerals those are initiate in the district.

\section{Analysis of fluoride in water}

Water samples from various drinking water sources (hand pumps, open wells and tube wells) were collected from 355 villages/sites of Mahendergarh district to determine the level of fluoride. Geographic locations of sampling sites were mapped by using Global Positioning System (GPS). Samples were collected in prewashed plastic bottles and carried to the laboratory. The collected samples were kept in dark place at room temperature in plastic containers until the fluoride analysis was done. Ion-selective electrode (ISE) method was used to determine the fluoride content in drinking water.

Electrode was calibrated using a series of known concentrations of fluoride. Standards and samples were mixed with 1:1 with a total ion strength adjustment buffer (TISAB) to minimize the effects of varying ionic strength and interference from other ions. TISAB was made by using 4.00 g CDTA (cyclohexanedi-amino-NNN1N1 tetra acetic Acid $)+57 \mathrm{~g} \mathrm{NaCL}$ and $57 \mathrm{~g}$ glacial acidic acid in $1 \mathrm{~L}$ of 


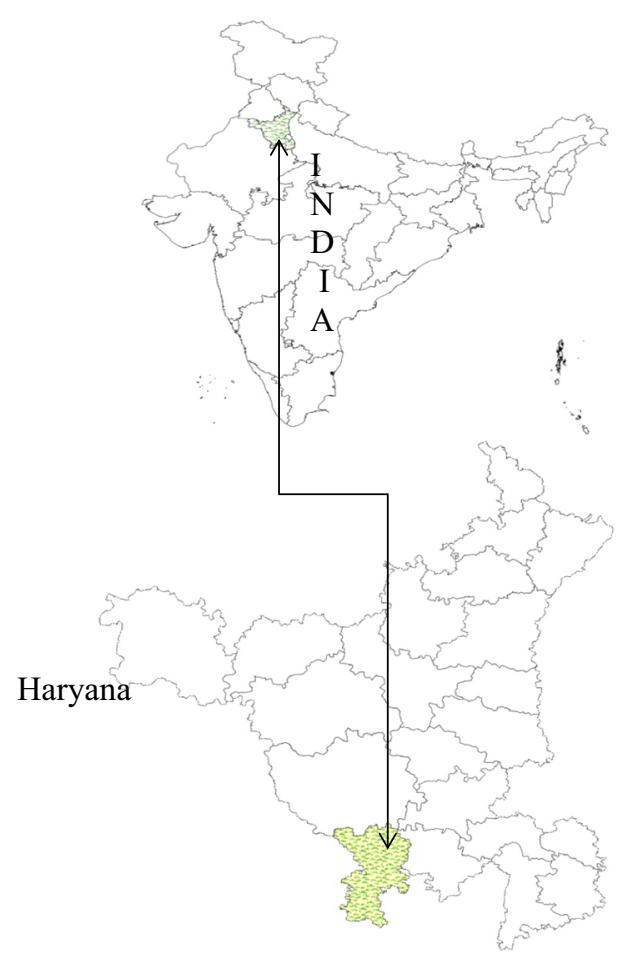

Fig. 1 Map of study area

distilled water. The solution $\mathrm{pH}$ was adjusted between 5.0 and 5.5 with $5 \mathrm{M} \mathrm{NaOH}$. After adding $25 \mathrm{ml}$ TISAB to $25 \mathrm{ml}$ of a water sample, fluoride concentration was measured with a fluoride ion-selective electrode in $\mathrm{mg} / \mathrm{l}$ or $\mathrm{ppm} / \mathrm{l}$. The different concentrations of $\mathrm{NaF}$ ranging from 0.1 to $100 \mathrm{ppm}$ were used for preparation of standard curve of fluoride. Suitable statistical techniques and graphical representations were used for analysis. GIS tools are used to show the fluoride concentration on map.

\section{Results}

Ground water fluoride concentration at different sampling sites varied in different blocks of district Mahendegarh. Fluoride level in water samples of 24 villages of Satnali block was examined and found that fluoride concentration ranged from 0.3 to $1.2 \mathrm{mg} / \mathrm{l}$ (Table 1). The lowest concentration of fluoride was found in village Dalanwas and highest in Rathiwas. The study reveals that fluoride concentration in villages of Satnali block was found within upper prescribed limit of WHO.

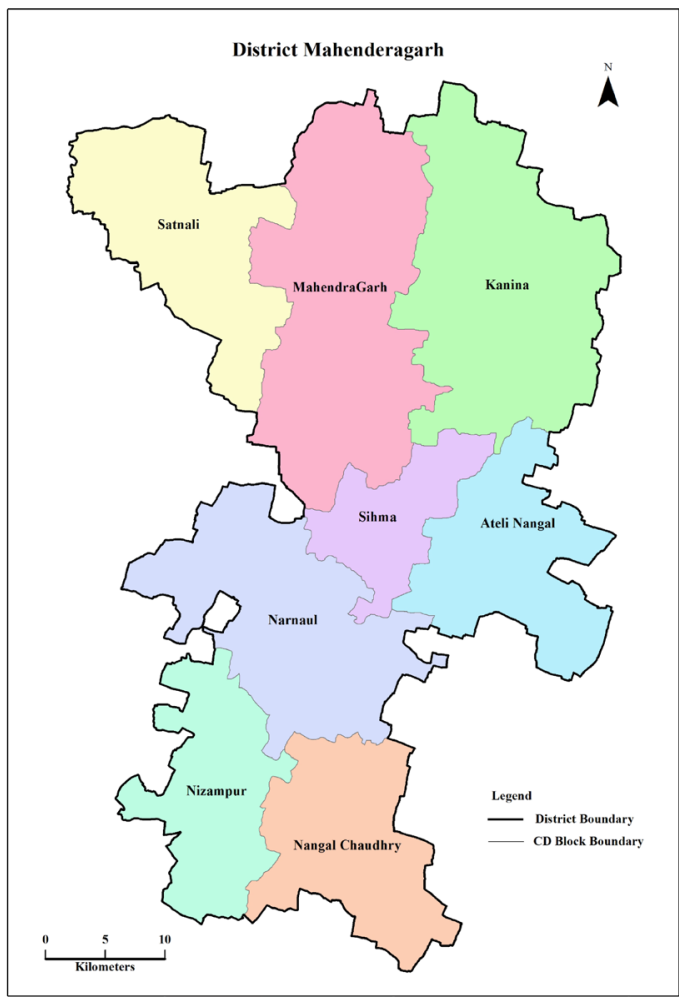

Table 1 Showing the average fluoride concentration in villages of block Satnali district Mahendergarh

\begin{tabular}{|c|c|c|c|c|c|}
\hline Sr. no. & $\begin{array}{l}\text { Village } \\
\text { name }\end{array}$ & $\begin{array}{l}\text { Fluoride } \\
\text { conc. in } \\
\mathrm{mg} / \mathrm{l}\end{array}$ & Sr. no. & $\begin{array}{l}\text { Village } \\
\text { name }\end{array}$ & $\begin{array}{l}\text { Fluoride } \\
\text { conc. in } \\
\mathrm{mg} / \mathrm{l}\end{array}$ \\
\hline 1. & Balana & 1.1 & 13. & $\begin{array}{r}\text { Nangal } \\
\text { Mala }\end{array}$ & 0.7 \\
\hline 2. & Barda & 0.9 & 14. & Nanwan & 0.8 \\
\hline 3. & Basri & 0.7 & 15. & Patharwa & 0.8 \\
\hline 4. & Bass & 0.6 & 16. & Rajawas & 0.9 \\
\hline 5. & Birsinghwas & 1.0 & 17. & Rathiwas & 1.2 \\
\hline 6. & Dalanwas & 0.3 & 18. & Satnali & 0.9 \\
\hline 7. & Dhadot & 0.4 & 19. & Shyampura & 0.5 \\
\hline 8. & Dhana & 0.7 & 20. & Sohla & 0.5 \\
\hline 9. & Digrota & 0.8 & 21. & Sohri & 0.7 \\
\hline 10. & Gadarwas & 0.9 & 22. & $\begin{array}{l}\text { Sureti } \\
\text { Jhakal }\end{array}$ & 0.6 \\
\hline 11. & Jarwa & 1.1 & 23. & $\begin{array}{l}\text { Sureti Mun- } \\
\text { dian }\end{array}$ & 0.5 \\
\hline 12. & Madhogarh & 0.7 & 24. & $\begin{array}{l}\text { Sureti } \\
\text { Pilania }\end{array}$ & 0.5 \\
\hline
\end{tabular}


Table 2 Showing the average fluoride concentration in villages of block Mahendergarh

\begin{tabular}{|c|c|c|c|c|c|}
\hline Sr. no. & Village name & $\begin{array}{l}\text { Fluoride conc. in } \\
\mathrm{mg} / \mathrm{l}\end{array}$ & Sr. no. & Village name & $\begin{array}{l}\text { Fluoride } \\
\text { conc. in } \\
\mathrm{mg} / \mathrm{l}\end{array}$ \\
\hline 1 & Adalpur & 0.7 & 33 & Khatiwas & 1.7 \\
\hline 2 & Akoda & 0.8 & 34 & Khatod & 1.2 \\
\hline 3 & Balaicha & 1.5 & 35 & Khatodra & 1.1 \\
\hline 4 & Basai & 1.6 & 36 & Kherki & 0.8 \\
\hline 5 & Bawana & 1.4 & 37 & Kheroli & 1.0 \\
\hline 6 & Beri & 2.0 & 38 & Khudana & 0.7 \\
\hline 7 & Bhagdana & 2.2 & 39 & Kothal Kalan & 1.5 \\
\hline 8 & Bhandor Nichi & 1.9 & 40 & Kothal Khurd & 1.1 \\
\hline 9 & Bhandor Unchi & 1.6 & 41 & Kuksi & 3.4 \\
\hline 10 & Bhurjat & 1.3 & 42 & Kurhawata & 1.0 \\
\hline 11 & Bucholi & 1.4 & 43 & Lawan & 0.9 \\
\hline 12 & Budian & 1.7 & 44 & Mahendergarh & 5.8 \\
\hline 13 & Bundebaz Nagar & 1.3 & 45 & Malra & 0.9 \\
\hline 14 & Chamdhera & 1.2 & 46 & Mandola & 0.8 \\
\hline 15 & Chhajiawas & 1.2 & 47 & Mazara Kalan & 2.1 \\
\hline 16 & Chitlong & 1.1 & 48 & Mazara Khurd & 0.6 \\
\hline 17 & Deroli Jat & 5.0 & 49 & Nanagwas & 0.8 \\
\hline 18 & Dewas & 2.2 & 50 & Nangal Sirohi & 1.5 \\
\hline 19 & Dholi & 1.0 & 51 & Nihalawas & 0.5 \\
\hline 20 & Dulana & 0.9 & 52 & Nambhera & 4.2 \\
\hline 21 & Duloth Ahir & 1.7 & 53 & Nimbi & 1.6 \\
\hline 22 & Gadnia & 2.9 & 54 & Paiga & 1.1 \\
\hline 23 & Garhi & 3.2 & 55 & Pal & 0.6 \\
\hline 24 & Gulawala & 1.8 & 56 & Palh & 1.6 \\
\hline 25 & Jant & 0.6 & 57 & Pali & 4.4 \\
\hline 26 & Jasawas & 1.8 & 58 & Palri Panihar & 3.0 \\
\hline 27 & Jatwas & 0.8 & 59 & Pharwas & 1.3 \\
\hline 28 & Jhanjariawas & 1.6 & 60 & Rewasa & 1.1 \\
\hline 29 & Jhook & 3.7 & 61 & Sisoth & 0.9 \\
\hline 30 & Jonawas & 0.9 & 62 & Ushmapur & 0.8 \\
\hline 31 & Khaira & 1.2 & 63 & Zairpur & 0.7 \\
\hline 32 & Khrkara/Aakoda & 0.8 & & & \\
\hline
\end{tabular}

The fluoride concentration in 63 villages of Mahendergarh block ranged from 0.5 to $5.8 \mathrm{mg} / \mathrm{l}$ (Table 2). The study reveals that out of 63 villages, 40 villages (62\%) have fluoride concentration up to $1.5 \mathrm{mg} / \mathrm{l}$ that is within the permissible drinking water limit according to WHO and 23 (38\%) villages were above the permissible limit. The lowest fluoride level was reported $0.5 \mathrm{mg} / \mathrm{l}$ from Nihalawas village and highest level $5.8 \mathrm{mg} / \mathrm{l}$ from Mahendergarh.

The fluoride concentration in 29 villages of Sihma block ranged from 0.9 to $6.0 \mathrm{mg} / \mathrm{l}$ with lowest in village Guwani and highest in Faizabad. The study reveals that out of 29 villages, 11 villages (38\%) have fluoride concentration within permissible limit according to WHO and 18 (62\%) villages above permissible limit (Table 3 ).
The fluoride concentration in 56 villages of Kanina block ranged from 0.4 to $2.5 \mathrm{mg} / \mathrm{l}$ with lowest in village Gudha and highest in Pathera. The study reveals that out of 56 villages, 50 villages (89\%) have fluoride concentration up to $1.5 \mathrm{mg} / \mathrm{l}$ that is under permissible limit of drinking water and $06(11 \%)$ villages above permissible limit (Table 4$)$.

The fluoride concentration in 43 villages of Ateli block ranged from 0.4 to $3.8 \mathrm{mg} / \mathrm{l}$ with lowest in villages of Ganiyar, Beghpur, Sujapur and Tobra and highest in Kunjpura (Table 5). The study reveals that out of 43 villages, 36 villages $(84 \%)$ have fluoride level within prescribed limit of $1.5 \mathrm{mg} / \mathrm{l}$ and 07 (16\%) villages above permissible limit.

The fluoride concentration in 64 villages of Narnaul block ranged from 0.9 to $16.0 \mathrm{mg} / \mathrm{l}$ with lowest in village 
Table 3 Showing the average fluoride concentration in villages of block Sihma district Mahendergarh

\begin{tabular}{|c|c|c|c|c|c|}
\hline Sr. no. & $\begin{array}{l}\text { Village } \\
\text { name }\end{array}$ & $\begin{array}{l}\text { Fluoride } \\
\text { conc. in } \\
\mathrm{mg} / \mathrm{l}\end{array}$ & Sr. no. & $\begin{array}{l}\text { Village } \\
\text { name }\end{array}$ & $\begin{array}{l}\text { Fluoride } \\
\text { conc. in } \\
\mathrm{mg} / 1\end{array}$ \\
\hline 1 & $\begin{array}{c}\text { Akbarpur } \\
\text { Ramu }\end{array}$ & 3.5 & 16 & Khashpur & 1.7 \\
\hline 2 & Atali & 4.9 & 17 & Khatripur & 1.2 \\
\hline 3 & $\begin{array}{l}\text { Azam } \\
\text { Nagar }\end{array}$ & 1.0 & 18 & Mayee & 3.1 \\
\hline 4 & $\begin{array}{l}\text { Chapra } \\
\text { Salimpur }\end{array}$ & 5.0 & 19 & Mittarpura & 5.8 \\
\hline 5 & Deroli Ahir & 4.0 & 20 & $\begin{array}{r}\text { Mundia } \\
\text { Khera }\end{array}$ & 1.8 \\
\hline 6 & $\begin{array}{c}\text { Dhongra } \\
\text { Ahir }\end{array}$ & 1.1 & 21 & Nuni Kalan & 2.5 \\
\hline 7 & Dongra Jat & 1.0 & 22 & Rampura & 5.9 \\
\hline 8 & Dublana & 2.0 & 23 & Sagarpur & 1.0 \\
\hline 9 & Duloth Jat & 2.2 & 24 & Saharpur & 1.0 \\
\hline 10 & Faizabad & 6.0 & 25 & Saluni & 2.3 \\
\hline 11 & Guwani & 0.9 & 26 & Seehma & 3.3 \\
\hline 12 & Hudina & 2.6 & 27 & Silarpur & 1.7 \\
\hline 13 & Jat Guwana & 1.4 & 28 & Surana & 3.1 \\
\hline 14 & Kalwari & 1.0 & 29 & Surani & 1.1 \\
\hline 15 & Khampura & 1.3 & & & \\
\hline
\end{tabular}

Mandhana and highest in Narnaul. The study reveals that out of 64 villages, only 8 villages $(12.5 \%)$ have fluoride concentration within permissible limit of $1.5 \mathrm{mg} / \mathrm{l}$ and 35 villages lied in less critical range within the range of 1.6 to $2.5 \mathrm{mg} / \mathrm{l}$ and 21 villages have fluoride concentration above $2.5 \mathrm{mg} / \mathrm{l}$ (Table 6).

The concentration of fluoride in drinking water samples of 29 villages of Nizampur block ranged from 0.6 to $2.6 \mathrm{mg} / \mathrm{l}$ (Table 7). Lowest level was reported from village Nangal Dargu and highest in Ghatasher. The study reveals that out of 29 villages, 14 villages (52\%) have fluoride level $>1.5 \mathrm{mg} / \mathrm{l}$.

The level of fluoride in drinking water samples of 47 villages of Nangal Chaudhary block ranged from 0.5 to $8.0 \mathrm{mg} / \mathrm{l}$ with lowest in village Niamatpur and highest in Mulodhi (Table 8). The study reveals that out of 47 villages, 21 villages (44\%) have fluoride concentration up to $1.5 \mathrm{mg} / \mathrm{l}$ and $26(56 \%)$ villages more than $1.5 \mathrm{mg} / \mathrm{l}$.

Fluoride distribution map of district Mahendergarh is shown in Fig. 2. Fluoride distribution in the drinking water of 355 villages has been depicted in the map. The fluoride concentration in Mahendergarh district ranged from 0.3 to $16.0 \mathrm{mg} / \mathrm{l}$ in ground water samples with lowest value of $0.3 \mathrm{mg} / \mathrm{l}$ in Dalanwas village of Satnali block and highest value of $16.0 \mathrm{mg} / \mathrm{l}$ in Naurnaul city of Narnaul block (Table 9, Fig. 3). The outcome of the present study revealed that out of 355 villages of district Mahendergarh, 205 villages (58\%) have fluoride level up to
Table 4 Showing the average fluoride concentration in villages of block Kanina district Mahendergarh

\begin{tabular}{|c|c|c|c|c|c|}
\hline Sr. no. & $\begin{array}{l}\text { Village } \\
\text { name }\end{array}$ & $\begin{array}{l}\text { Fluoride } \\
\text { conc. in } \\
\mathrm{mg} / \mathrm{l}\end{array}$ & Sr. no. & $\begin{array}{l}\text { Village } \\
\text { name }\end{array}$ & $\begin{array}{l}\text { Fluoride } \\
\text { conc. in } \\
\mathrm{mg} / \mathrm{l}\end{array}$ \\
\hline 1 & Aghiar & 1.2 & 29 & Khairani & 0.6 \\
\hline 2 & Anawas & 1.2 & 30 & $\begin{array}{l}\text { Kharkara } \\
\text { Bass }\end{array}$ & 1.6 \\
\hline 3 & Bachiani & 0.8 & 31 & Khera & 1.0 \\
\hline 4 & Bawania & 0.7 & 32 & Kheri & 1.5 \\
\hline 5 & Bewal & 1.6 & 33 & Koka & 0.9 \\
\hline 6 & Bhagot & 0.6 & 34 & Kotia & 0.9 \\
\hline 7 & Bhalkhi & 0.7 & 35 & Manpura & 0.9 \\
\hline 8 & Bharap & 0.6 & 36 & Meghanwas & 1.1 \\
\hline 9 & Bhojawas & 0.5 & 37 & $\begin{array}{l}\text { Moham- } \\
\text { madpur }\end{array}$ & 1.0 \\
\hline 10 & Buchawas & 0.7 & 38 & Mori & 0.8 \\
\hline 11 & Chelawas & 0.5 & 39 & Mundian & 0.6 \\
\hline 12 & Chitroli & 2.1 & 40 & Nangal & 0.8 \\
\hline 13 & Dhana & 1.0 & 41 & Notana & 2.4 \\
\hline 14 & Dhanunda & 0.9 & 42 & Partal & 0.8 \\
\hline 15 & Gagarwas & 0.8 & 43 & Pathera & 2.5 \\
\hline 16 & Gahra & 0.8 & 44 & Pota & 0.8 \\
\hline 17 & Gomla & 1.0 & 45 & Rambas & 0.7 \\
\hline 18 & Gomli & 1.0 & 46 & Rasulpur & 0.5 \\
\hline 19 & Gudha & 0.4 & 47 & Sehlang & 1.0 \\
\hline 20 & Israna & 0.9 & 48 & Siana & 2.2 \\
\hline 21 & Jhagroli & 2.1 & 49 & Sigra & 1.5 \\
\hline 22 & Jharli & 1.0 & 50 & Sigri & 1.5 \\
\hline 23 & Jhijawan & 1.3 & 51 & Sihor & 0.9 \\
\hline 24 & Kaimla & 1.0 & 52 & Sundra & 1.0 \\
\hline 25 & Kakrala & 0.8 & 53 & Surjanwas & 1.2 \\
\hline 26 & Kapoori & 0.5 & 54 & Talwana & 1.0 \\
\hline 27 & Karira & 0.7 & 55 & Unchat & 2.3 \\
\hline 28 & Khairana & 0.8 & 56 & Unhani & 0.9 \\
\hline
\end{tabular}

$1.5 \mathrm{mg} / \mathrm{l}$ and 120 villages (34\%) have fluoride level varied in the range of 1.6 to $3.5 \mathrm{mg} / \mathrm{l}$ in drinking ground water, i.e., above the upper permissible limit of $1.5 \mathrm{mg} / \mathrm{l}$ as prescribed by WHO. 20 villages (5\%) have fluoride concentration of 3.6 to $5.5 \mathrm{mg} / \mathrm{l}$. In the present study, only ten villages (3\%) have fluoride concentration above $5.5 \mathrm{mg} / \mathrm{l}$ (Fig. 3) that may cause fluorosis among residents of the district.

\section{Discussion}

On the basis of fluoride distribution, the district Mahendergarh villages were categorized on the pattern of the previous study (Yadav et al. 2009). The villages 
Table 5 Showing the average fluoride concentration in villages of block Ateli district Mahendergarh

\begin{tabular}{|c|c|c|c|c|c|}
\hline Sr. no. & Village name & $\begin{array}{l}\text { Fluoride conc. } \\
\text { in } \mathrm{mg} / \mathrm{l}\end{array}$ & Sr. no. & Village name & $\begin{array}{l}\text { Fluoride } \\
\text { conc. in } \\
\mathrm{mg} / \mathrm{l}\end{array}$ \\
\hline 1 & Ateli Rural & 0.7 & 23 & Kunjpura & 3.8 \\
\hline 2 & Bachhod & 1.1 & 24 & Mahaser & 1.2 \\
\hline 3 & Bazar & 0.5 & 25 & Mirzapur & 1.3 \\
\hline 4 & Beghpur & 0.4 & 26 & Mohlera & 1.6 \\
\hline 5 & Bhilwara & 0.7 & 27 & Mohmadpur & 1.0 \\
\hline 6 & Bhori & 0.9 & 28 & Nangal & 1.2 \\
\hline 7 & Bihali & 0.7 & 29 & Navadi & 0.9 \\
\hline 8 & Bocharya & 1.1 & 30 & Neerpur & 2.2 \\
\hline 9 & Chandpura & 0.6 & 31 & Prithvipura & 1.6 \\
\hline 10 & Dhanunda & 0.6 & 32 & Rajpura & 0.5 \\
\hline 11 & Fatehpur & 0.5 & 33 & Rampura & 0.8 \\
\hline 12 & Ganiyar & 0.4 & 34 & Rata Kalan & 2.2 \\
\hline 13 & Ghari Ruthal & 0.5 & 35 & RataKhurd & 1.6 \\
\hline 14 & Gokalpur & 0.5 & 36 & Saidpur & 0.5 \\
\hline 15 & Gujarwas & 0.5 & 37 & Salimpur & 0.8 \\
\hline 16 & Hasanpur & 1.0 & 38 & Sari Bahadur Nagar & 1.0 \\
\hline 17 & Kanti & 1.2 & 39 & Sujapur & 0.4 \\
\hline 18 & Kariya & 1.0 & 40 & Tajpur & 0.5 \\
\hline 19 & Katkai & 1.5 & 41 & Tigra & 0.7 \\
\hline 20 & Khariwara & 1.0 & 42 & Tobra & 0.4 \\
\hline 21 & Kheri & 3.2 & 43 & Uninda & 0.5 \\
\hline 22 & Khor & 0.8 & & & \\
\hline
\end{tabular}

have been divided into six categories: up to $0.5 \mathrm{mg} / 1$, 0.6-1.5 mg/1, 1.6-2.5 mg/1, 2.6-3.5 mg/1, 3.6-4.5 mg/1, $4.6-5.5 \mathrm{mg} / \mathrm{l}$ and $>5.5 \mathrm{mg} / \mathrm{l}$. Out of 355 villages of the Mahendergarh district, 150 villages were reported for having fluoride values more than the permissible limit of $1.5 \mathrm{mg} / \mathrm{l}$ as prescribed by WHO and 218 villages having fluoride values more than the maximum permissible limit $(1.0 \mathrm{mg} / \mathrm{l})$ prescribed by Bureau of Indian Standard. Various studies from many parts of the world depicted higher concentration of fluoride in ground water. Boyle and Chagnon (1995) conducted a study on fluoride concentration in water from Gaspe Peninsula of Quebec, Canada, where concentration of fluoride in shallow wells was reported up to $28 \mathrm{mg} / \mathrm{l}$. Gopalakrishnan et al. (2012) conducted a survey in Manur block of Tirunelveli district, Tamil Nadu, South India. Alavanthankulam and Pappankulam were found as high fluoride endemic areas having fluoride level 3.6 and $2.00 \mathrm{mg} / 1$, respectively. Behara et al. (2014) conducted a survey of Purulia district, West Bengal, India; 84 water samples from different sources were collected during Jan, 2013. The fluoride concentration was reported from 0.126 to $8.16 \mathrm{ppm}$. Out of total, 23 water samples were found with high fluoride concentration.
The studies have also been done in Haryana to analyze the fluoride concentration in groundwater. Meenakshi et al. (2004) conducted a survey to analyze the fluoride concentration in Jind district, Haryana state. The result showed that the fluoride content ranges from 0.3 to $6.9 \mathrm{mg} / \mathrm{l}$. Bishnoi and Arora (2007) conducted a survey to determine fluoride distribution in ground water in ten villages of district Rohtak, Haryana. Out of 63 water samples, 30 water samples around $50 \%$ samples exceeded the permissible limit. The fluoride content ranges from 0.034 to $2.09 \mathrm{mg} / \mathrm{l}$. Manjeet et al. (2014) carried out a survey from different villages of district Gurgaon from different water sources to assess the quality of groundwater. Fluoride level was reported between 0.02 and $6.4 \mathrm{mg} / \mathrm{l}$ and analyzed from 97 water samples. Kumar et al. (2017) analyzed relationship between water, urine and serum fluoride from Jhajjar district. Average fluoride values in water samples of Jhajjar city and Dadanpur and Dariyapur villages of Jhajjar District were measured 2.17, 2.81 and $2.22 \mathrm{mg} / \mathrm{l}$, respectively. Kumar and Sharma (2017) conducted a survey of Hisar city to analyze the ground quality and found that the fluoride concentration ranges from 0.5 to $2.98 \mathrm{mg} / \mathrm{l}$.

Fluoride concentration above $1.5 \mathrm{mg} / \mathrm{l}$ in drinking water causes many types of diseases mainly dental and skeleton fluorosis. Mahendergarh district has a rural background, 
Table 6 Showing the average fluoride concentration in villages of block Narnaul district Mahendergarh

\begin{tabular}{|c|c|c|c|c|c|}
\hline Sr. no. & Village name & $\begin{array}{l}\text { Fluoride conc. in } \\
\mathrm{mg} / \mathrm{l}\end{array}$ & Sr. no. & Village name & $\begin{array}{l}\text { Fluoride } \\
\text { conc. in } \\
\mathrm{mg} / \mathrm{l}\end{array}$ \\
\hline 1 & Amarpur Jorasi & 1.8 & 33 & Kojinda & 1.3 \\
\hline 2 & Badopur & 1.7 & 34 & Koriawas & 1.9 \\
\hline 3 & Bahkahri & 1.8 & 35 & Kultajpur & 2.5 \\
\hline 4 & Balaha Kalan & 2.1 & 36 & Kutbapur & 2.3 \\
\hline 5 & Balaha Khurd & 1.8 & 37 & Lehroda & 1.2 \\
\hline 6 & Baproli & 2.5 & 38 & Maksuspur & 1.8 \\
\hline 7 & Bargaon & 2.3 & 39 & Mandhana & 0.9 \\
\hline 8 & Barkoda & 1.0 & 40 & Mandlana & 4.5 \\
\hline 9 & Bas Kirarod & 4.5 & 41 & Mehrampur & 2.2 \\
\hline 10 & Bhusan Kalan & 2.6 & 42 & Mohanpur & 2.4 \\
\hline 11 & Bhushan Khurd & 3.2 & 43 & Mukandpura & 1.5 \\
\hline 12 & Chindalia & 1.7 & 44 & Muraripur & 8.0 \\
\hline 13 & Dhani Bhatotha & 2.4 & 45 & Nangal Khata & 2.4 \\
\hline 14 & Dhani Kirarod & 5.2 & 46 & Nangal Sailu & 2.2 \\
\hline 15 & Dharson & 3.9 & 47 & Nangtihari & 3.2 \\
\hline 16 & Dochana & 1.9 & 48 & Narnaul & 16.0 \\
\hline 17 & Dohar Kalan & 2.1 & 49 & Nasibpur & 2.5 \\
\hline 18 & Dohar Khurd & 2.0 & 50 & Neerpur & 1.4 \\
\hline 19 & Gehli & 3.6 & 51 & Niwaj Nagar & 4.3 \\
\hline 20 & Goad & 2.0 & 52 & Nuni Kalan & 2.0 \\
\hline 21 & Hamidpur & 2.1 & 53 & Patikara & 3.3 \\
\hline 22 & Hazipur & 4.0 & 54 & Raghunathpura & 4.6 \\
\hline 23 & Jadupur & 2.0 & 55 & Rasulpur & 1.2 \\
\hline 24 & Jailaf & 2.2 & 56 & Sekha & 1.2 \\
\hline 25 & Jakhni & 1.9 & 57 & Sekhpura & 1.6 \\
\hline 26 & Kanwi & 5.8 & 58 & Seonathpura & 1.6 \\
\hline 27 & Karota & 4.1 & 59 & Shapur Mandi & 1.8 \\
\hline 28 & Khanpur & 1.7 & 60 & Silarpur Mehta & 4.2 \\
\hline 29 & Khatoti Kalan & 2.7 & 61 & Sobhapur & 1.7 \\
\hline 30 & Khatoti Khurd & 2.0 & 62 & Tajipur & 4.8 \\
\hline 31 & Khorma & 2.8 & 63 & Tehla & 1.7 \\
\hline 32 & Kirarod Afgan & 3.0 & 64 & Thana & 1.8 \\
\hline
\end{tabular}

and it is an industrial free zone and has no industrial input. Main occupation of the residents is agriculture, so industrial aerosols are not responsible for higher concentration of fluoride. Possible contributor of fluoride in ground water is due to geology of the area and fertilizers used in agriculture. Geologically, the rocks in this area belong to Delhi super groups and divided into two groups. The Purana rocks of upper pre-Cambrian age belong to Ajabgarh, series of Delhi system. The rocks of the Huranian period belong to Archaen Dharwar system, and rocks of these groups consist of biotite, slates, phyllits, quartzite, limestone, gneiss and sand stones. Fluorine is found in primary minerals, specially biotites and amphiboles. On weathering, fluorine leaches out from these minerals and constitutes a major source of fluoride in ground water. Other reasons of higher concentration in some villages may be due to deeper water table and climatic conditions. Deeper ground water in bore holes is considered to contain high concentration of fluoride than shallow ground water bore hole. Climatic conditions are also responsible for variations in fluoride concentration (Handa 1975). Mahendergarh district lies in arid climatic condition zone where ground water infiltration and flow rates are slow. Such climatic conditions provide long duration for reaction between water and rocks which results in high fluoride level in ground water. 
Table 7 Showing the average fluoride concentration in villages of block Nizampur district Mahendergarh

\begin{tabular}{llllll}
\hline Sr. no. & $\begin{array}{l}\text { Village } \\
\text { name }\end{array}$ & $\begin{array}{l}\text { Fluoride } \\
\text { conc. in } \\
\mathrm{mg} / \mathrm{l}\end{array}$ & Sr. no. & $\begin{array}{l}\text { Village } \\
\text { name }\end{array}$ & $\begin{array}{l}\text { Fluoride } \\
\text { conc. in } \\
\mathrm{mg} / \mathrm{l}\end{array}$ \\
\hline 1 & Bamanwas & 1.3 & 16 & Maroli & 1.8 \\
2 & Basirpur & 2.2 & 17 & Mukhota & 1.2 \\
3 & Bayal & 2.5 & 18 & Musnota & 1.2 \\
4 & Beghopur & 1.5 & 19 & Nangal & 0.6 \\
& Berundla & 2.1 & 20 & Napla & 1.2 \\
5 & Chillro & 1.7 & 21 & Niaz Alipur & 1.0 \\
6 & Dhancholi & 1.6 & 22 & Nerhari & 1.2 \\
7 & Dhanota & 2.2 & 23 & Nizampur & 1.7 \\
8 & Gangutana & 1.8 & 24 & Panchnota & 1.0 \\
9 & Ganwaru Jat & 2.3 & 25 & Pavera & 1.1 \\
10 & Ghatasher & 2.6 & 26 & Rambass & 2.0 \\
11 & Golwa & 0.8 & 27 & Rooper & 1.0 \\
12 & & & & Sarai & \\
13 & Hasanpur & 1.5 & 28 & Sareli & 1.1 \\
14 & Islampura & 1.2 & 29 & Talot & 2.4 \\
15 & Karoli & 2.1 & & & \\
\hline
\end{tabular}

\section{Conclusion}

Mahendergarh district is one of the district of Haryana known for high fluoride level where majority of resident's use underground water for drinking purpose. Fluoride level was measured in underground drinking water from 355 villages in the present study. Satnali block villages totally fall within the upper permissible limit of $1.5 \mathrm{mg} / \mathrm{l}$ fluoride level according to WHO. Kanina, Ateli and Nizampur blocks have normal fluoride contaminated drinking water. Narnaul block villages were found to have maximum concentration of fluoride level. Main fluoride problem persists in Mahendergarh, Sihma, Narnaul and Nangal Chaudhary blocks. Mahendergarh District is industrial free zone. The main economy of the people depends on agriculture. It lies in semiarid zone, and water table is very low. Higher fluoride range in ground water is due to the presence of fluoride bearing mineral rocks. The present study will be helpful to mitigate the problem of high fluoride level through implementation of program by government and NGO to achieve the goal of health for all.
Table 8 Showing the average fluoride concentration in villages of block Nangal Chaudhary district Mahendergarh

\begin{tabular}{|c|c|c|c|c|c|}
\hline Sr. no. & Village name & $\begin{array}{l}\text { Fluoride conc. in } \\
\mathrm{mg} / \mathrm{l}\end{array}$ & Sr. no. & Village name & $\begin{array}{l}\text { Fluoride } \\
\text { conc. in } \\
\mathrm{mg} / \mathrm{l}\end{array}$ \\
\hline 1 & Akbarpur Sirohi & 1.3 & 25 & Kamania & 3.2 \\
\hline 2 & Akoli & 1.8 & 26 & Khatoli Ahir & 3.5 \\
\hline 3 & Amarpura & 1.6 & 27 & Khatoli Jat & 3.2 \\
\hline 4 & Antri & 1.5 & 28 & Lujota & 2.9 \\
\hline 5 & Asrawas & 0.8 & 29 & Mausampur & 2.2 \\
\hline 6 & Bamanwas Kheta & 1.0 & 30 & Meghot Binja & 0.8 \\
\hline 7 & Banihari & 1.5 & 31 & Meghot Halla & 2.3 \\
\hline 8 & Bhadenti & 1.4 & 32 & Mourund & 0.8 \\
\hline 9 & Bhiharipur & 1.0 & 33 & Mulodi & 8.0 \\
\hline 10 & Bhojawas & 5.9 & 34 & Nangal Kalia & 1.3 \\
\hline 11 & Bhngarka & 6.2 & 35 & Nangal Nunia & 2.5 \\
\hline 12 & Budhwal & 2.9 & 36 & Nangal Pipa & 1.7 \\
\hline 13 & Chapra nipur & 4.6 & 37 & Nangal Soda & 2.1 \\
\hline 14 & Chekmalikpur & 1.5 & 38 & Nayan & 2.0 \\
\hline 15 & Datal & 1.6 & 39 & Niamatpur & 0.5 \\
\hline 16 & Dholera & 2.3 & 40 & Rai Malikpur & 1.0 \\
\hline 17 & Dokhera & 0.8 & 41 & Saidalipur & 1.3 \\
\hline 18 & Dongli & 1.2 & 42 & Sehbajpur & 1.0 \\
\hline 19 & Dostpur & 1.5 & 43 & Serohi Bhali & 2.7 \\
\hline 20 & Nehru Nagar & 1.8 & 44 & Sheonathpura & 0.8 \\
\hline 21 & Gothri & 0.8 & 45 & Simli & 2.2 \\
\hline 22 & Iqbalpur Nangli & 3.2 & 46 & Thanwas & 1.5 \\
\hline 23 & Jainpur & 2.1 & 47 & Totaheri & 1.8 \\
\hline 24 & Kalba & 3.3 & & & \\
\hline
\end{tabular}


Fig. 2 Fluoride concentration distribution map of district Mahendergarh

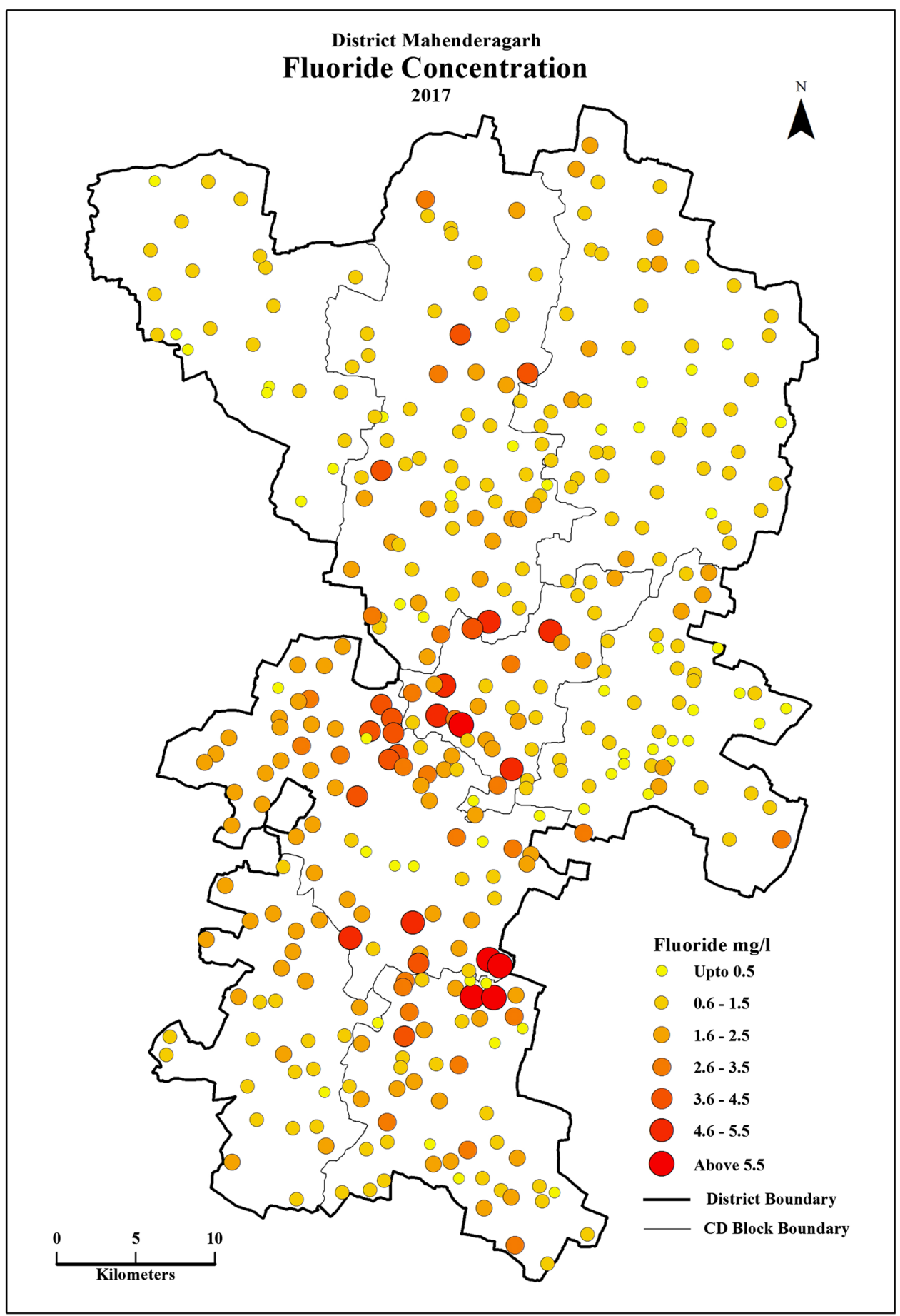


Table 9 Fluoride distribution in all the eight blocks of district Mahendergarh

\begin{tabular}{llllllllll}
\hline Name of blocks/nos. of villages & \multicolumn{7}{l}{ Fluoride concentration in mg/l } \\
\cline { 2 - 9 } & Min. & Max. & Up to 0.5 & $0.6-1.5$ & $1.6-2.5$ & $2.6-3.5$ & $3.6-4.5$ & $4.6-5.5$ & $>5.5$ \\
\hline Nizampur/29 & 0.6 & 2.6 & Nil & $15(51.72 \%)$ & $13(44.82 \%)$ & $01(3.44 \%)$ & - & - \\
Narnaul/64 & 0.9 & 16.0 & Nil & $8(12.5 \%)$ & $35(54.68)$ & $7(10.93 \%)$ & $8(12.5 \%)$ & $3(4.68 \%)$ & $3(4.68 \%)$ \\
Nangal Chaudhary/47 & 0.5 & 8.0 & $1(2.1 \%)$ & $20(42.55 \%)$ & $14(29.78 \%)$ & $8(17.02 \%)$ & Nil & $1(2.1 \%)$ & $3(6.38 \%)$ \\
Satnali/24 & 0.3 & 1.2 & $7(29.16 \%)$ & Nil & Nil & Nil & Nil & Nil & Nil \\
Kanina/56 & 0.4 & 2.5 & $4(7.14 \%)$ & $46(82.14 \%)$ & $6(10.71 \%)$ & Nil & Nil & Nil & Nil \\
Mahendergarh/63 & 0.5 & 5.8 & $1(1.58 \%)$ & $39(61.90 \%)$ & $14(22.22 \%)$ & $4(6.34 \%)$ & $3(4.76 \%)$ & $1(1.58 \%)$ & $1(1.58 \%)$ \\
Sihma/29 & 0.9 & 6.0 & Nil & $11(37.93 \%)$ & $7(24.13 \%)$ & $5(17.24 \%)$ & $1(3.44 \%)$ & $2(6.89 \%)$ & $3(10.34 \%)$ \\
Ateli/43 & 0.3 & 3.8 & $14(32.55 \%)$ & $22(51.16 \%)$ & $5(11.62 \%)$ & $1(2.32 \%)$ & $1(2.32 \%)$ & Nil & Nil \\
Total villages =355 & & & 27 & 178 & 94 & 26 & 13 & 7 & 10 \\
\hline
\end{tabular}

Fig. 3 Fluoride concentration in underground water of different blocks of Mahendergarh

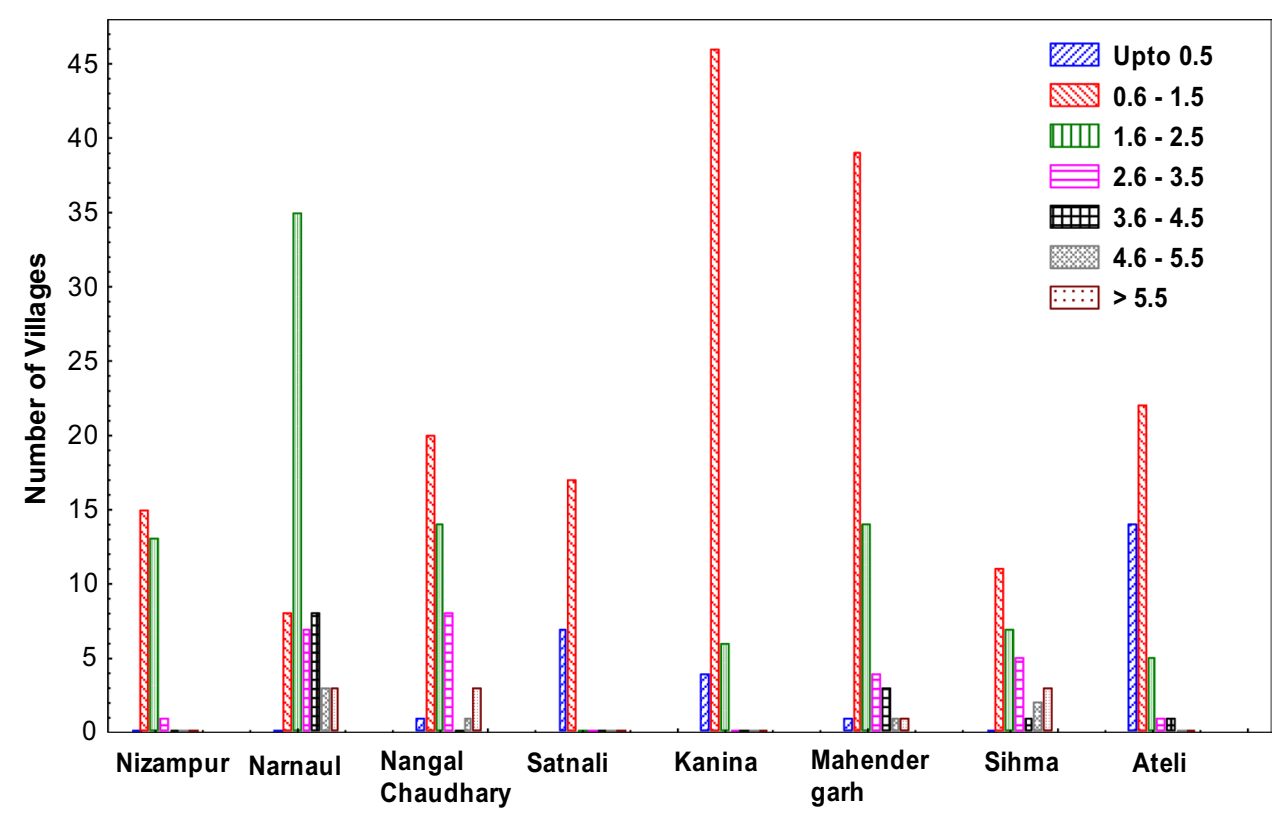

Acknowledgements Mrs. Sucheta Yadav would like to thank University Grants Commission, New Delhi, for the award of Teacher Fellowship and Department of Higher Education, Haryana Govt., for sanction of study leave.

Open Access This article is distributed under the terms of the Creative Commons Attribution 4.0 International License (http://creativeco mmons.org/licenses/by/4.0/), which permits unrestricted use, distribution, and reproduction in any medium, provided you give appropriate credit to the original author(s) and the source, provide a link to the Creative Commons license, and indicate if changes were made.

\section{References}

Alabdulaaly AI, Al-Zarah AI, Khan MA (2013) Occurrence of fluoride in groundwater of Saudi Arabia. Appl Water Sci 3:589-595

Ayoob S, Gupta AK (2006) Fluoride in drinking water: a review on the status and stress effects. Crit Rev Environ Sci Technol 36:433487. https://doi.org/10.1080/10643380600678112
Behara B, Kumar N, Mohrana M (2014) Assessment of groundwater pollution due to fluoride concentration and water quality in and around Purulia district, West Bengal, India. J Chem Pharm Res 6(8):384-392

Bishnoi M, Arora S (2007) Potable groundwater quality in some villages of Haryana, India: focus on fluoride. J Environ Biol 28(2):291-294

Bonvicini G, Fregni A, Palmonari C (2006) Fluorine compounds from industrial sources: the case study of ceramic industries. In: Tressaud A (ed) Fluorine and the environment: atmospheric chemistry, emissions, and lithosphere, 1(7). Elsevier, Amsterdam, pp 225-249

Bouletreau PH, Bost M, Fontanges E, Lauverjat M, Gutkneeht C, Ecohard R, Delmas PD, Chambrier C (2006) Fluoride exposure and bone status in patients with chronic intestinal failure who are receiving home parental nutrition. Am J Nutr 83:1429-1437

Boyle DR, Chagnon M (1995) An incidence of skeletal fluorosis associated with ground waters of the maritime carboniferous baron, Gaspe Region, Quebec, Canada. Environ Geochem Health 17:5-12 
Cronin SJ, Manoharan V, Hedley MJ, Longanathan P (2000) Fluoride: a review of fluorosis in grazed-pasture systems in New Zealand. N Z J Agric Res 43:295-321

Dahariya NS, Rajhans PK (2015) Fluoride contamination of groundwater and health hazard in central India. J Water Resour Proc 7:1416-1428

Dhanya R, Shaji E (2017) Fluoride contamination in groundwater resources of Alleppey, southern India. Geosci Front 8(1):117-124

Dissanayake CB (1991) The fluoride problem in the groundwater of Sri Lanka — environmental management and health. Int J Environ Stud 38:137-156

Edmunds WM, Smedley PL (2005) Fluoride in natural waters. Elsevier Academic Press, Burlington, pp 301-309

EPA (1997) Public health global for fluoride in drinking water, pesticide and environmental toxicology, section office of environmental health hazard assessment. California Environmental Protection Agency, California

Feng YW, Ogura N, Feng ZW, Zhang F, Shomizes H (2003) The concentrations and sources of fluoride in atmospheric depositions of Beijing, China. Water Air Soil Pollut 45(1-4):95-107

Fornasiero RB (2001) Phototoxic effects of fluoride. Plant Sci 161:979-985

Fuge R, Andrews MJ (1988) Fluorine in the UK environment. Environ Geochem Health 10(3-4):96-104. https://doi.org/10.1007/13F01 758677

Gikunju JK, Githui K, Maitho TE (1992) Fluoride levels in borehole water around Nairobi. Fluoride 25:111-114

Gopalakrishnan SB, Vishwanathan G, Siva Ilango S (2012) Prevalence of fluorosis and identification of fluoride endemic areas in Manur block of Tirunelveli district, Tamilnadu, South India. Appl Water Sci 2:235-243

Gupta SC, Rathore GS, Doshi CS (1993) Fluoride distribution in groundwaters of southeastern Rajasthan. Ind J Environ Health 35:97-109

Handa BK (1975) Geochemistry and genesis of fluoride containing ground waters in India. Groundwater 13(3):275-281

Indu R, Krishnan S, Shah T (2007) Impacts of groundwater contamination with fluoride and arsenic: affliction severity, medical cost and wage loss in some villages of India. Int J Rural Manas 3:69-93

Kumar S, Sharma SK (2017) Groundwater quality of Hisar city of Haryana state, India—status of fluoride content. Int J Chem Sci 15(4): $1-10$

Kumar SPJ, Jegathambal P, James EJ (2014) Factors influencing the high fluoride concentration in groundwater of Vellor District, South India. Environ Earth Sci 72:2437-2446

Kumar S, Lata S, Yadav JP (2017) Relationship between water, urine and serum fluoride and fluorosis in school children of Jhajjar district, Haryana, India. Appl Water Sci 7(6):3377-3384

Kumari SD, Rao PR (1993) Endemic fluorosis in Madras Presidency, India. J Med Res 25:53-558
Kundu N, Tripathy S, Munshi S, Powell M, Hart B, Panigrahi M (2001) Geochemical appraisal of fluoride contamination of groundwater in Nayagarh district of Orissa, India. Environ Geol 41(3-4):451-460

Manjeet Singh BP, Sharma JK (2014) Assessment of quality of groundwater in some villages of Gurgaon district, Haryana, India: focus on fluoride. Int J Innov Res Sci Eng Technol 3(4):11441-11448

McDonagh MS, Whiting PF, Wilson PM, Sutton AJ, Chestnutt I, Cooper J, Misso K, Bradley M, Treasure E, Kleijnen J (2000) Systematic review of water fluoridation. Br Med J 321:855-859

Meenakshi, Garg VK, Kavita, Renuka, Malik A (2004) Groundwater quality in some villages of Haryana, India: focus on fluoride and fluorosis. J Hazard Mater 106(B):85-97

Messaitfa A (2008) Fluoride contents in ground water and the main consumed foods (dates and tea) in Southern Algeria region. Environ Geol 55:377-383

Park K (2011) Park's textbook of preventive and social medicine, 21st edn. M/S Banarsidas Bhanot, Jabalpur, India

Reddy AGS, Reddy DV, Rao PN, Prasad KM (2010) Hydro geochemical characterization of fluoride rich groundwater of Wailpalli watershed, Nalagonda district, Andhra Pradesh, India. Environ Monit Assess 171:561-577

Sushila AK (2001) Fluorosis in developing countries: remedial measures and approaches. Proc Ind Natl Sci Acad B 68(5):389-400

Sushila AK, Kumar A, Bhatnagar M, Bahadur R (1993) Prevalence of endemic fluorosis with gastrointestinal manifestation in people living in some north Indian villages. Fluoride 26(2):97-104

Teotia SP, Teotia M (1994) Dental caries: a disorder of high fluoride and low dietary calcium interactions. Fluoride 27:59-66

Walna B, Kurzyca I, Siepak J (2007) Variation in fluoride level in precipitation in a region of human impact. Water Air Soil Pollut Focus 7:33-40. https://doi.org/10.1007/s11267-006-9108-4

WHO (1984) Fluoride and fluorides environmental health criteria. World Health Organization, Geneva

WHO (2002) Environmental health criteria. Fluorides, vol 227. World Health Organization, Geneva, pp 1-251

WHO (2011) Guidelines for drinking-water quality. World Health Organization, Geneva

Yadav JP, Lata S, Kataria SK, Kumar S (2009) Fluoride distribution in groundwater and survey of dental fluorosis among school children in the villages of the Jhajjar District of Haryana, India. Environ Geochem Health 31:431-438

Publisher's Note Springer Nature remains neutral with regard to jurisdictional claims in published maps and institutional affiliations. 